\title{
Hydropneumothorax as an iatrogenic complication after nasogastric intubation
}

\author{
Hugo Jorge Casimiro, ${ }^{1,2}$ Joana Carreira, ${ }^{1}$ Beatriz Navarro, ${ }^{1}$ Mário Parreira ${ }^{1}$
}

'Internal Medicine, Centro Hospitalar de Setubal EPE, Setúbal, Portugal

${ }^{2}$ Instituto de Histologia e Biologia do Desenvolvimento, Universidade de Lisboa Faculdade de Medicina, Lisboa, Portugal

\section{Correspondence to} Dr Hugo Jorge Casimiro, hugojorgecasimiro@gmail.com

Accepted 5 August 2017

\section{CrossMark}

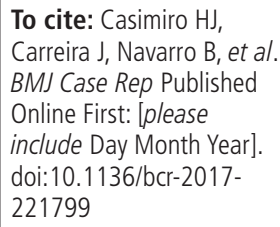

\section{DESCRIPTION}

A 62-year-old woman with history of frontotemporal dementia was admitted to a Psychiatry ward due to severe insomnia. In the morning, after the admission a nasogastric tube was placed to initiate enteral feeding and medication since she was refusing all oral intake. Later that night, she was found unresponsive, dyspnoeic and with severe hypotension. Physical examination identified clinical signs of respiratory distress and decreased vesicular breath sounds on the right hemithorax. The gasometric evaluation revealed the presence of hypoxaemia and lactic acidosis. A posteroanterior chest radiograph showed a right pleural effusion and a misplaced nasogastric tube (figure 1). A thoracic CT scan revealed the presence of a right hydropneumothorax and also identified a tube inside the trachea and the right main bronchus, which perforated the lung parenchyma and ended in the pleural cavity (figure 2).

It was assumed an iatrogenic complication after nasogastric intubation. The content obtained after pleural effusion drainage was consistent with food delivered through the nasogastric tube during breakfast and lunch. The patient was submitted to a right segmental lobectomy, with no immediate complications. She has been evaluated for the last 2 years, showing no respiratory symptoms or pulmonary dysfunction. She maintains regular Psychiatry consultations due to her frontotemporal dementia.

Nasogastric intubation is associated with iatrogenic complications in up to $8 \%$ of the cases. ${ }^{1}$ The

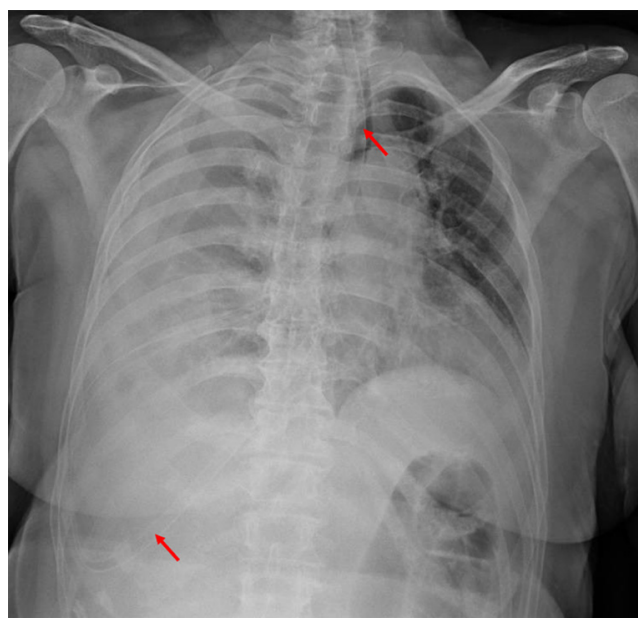

Figure 1 Posteroanterior chest radiograph showing right pleural effusion and a misplaced nasogastric tube (arrows).

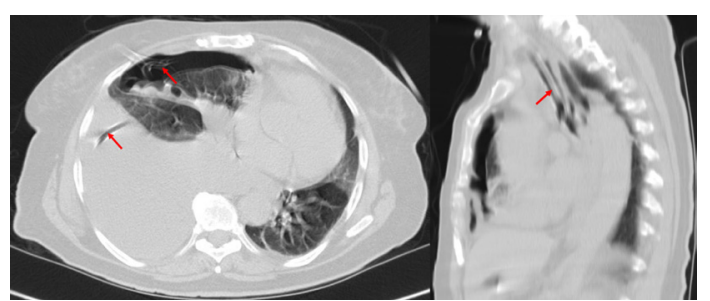

Figure 2 Thoracic CT scan showing right hydropneumothorax and also a tube inside the trachea and the right main bronchus, which perforated the lung parenchyma and ended in the pleural cavity (arrows).

most common ones are related to the respiratory system. ${ }^{2}$ In order to prevent such accidents, the use of auxiliary techniques such as the capnography and endoscopy during nasogastric intubation is recommended. ${ }^{3}$

\section{Learning points}

- latrogenic complications still play an important role in the daily activity in any medical institution and every clinician must be aware of them

- Nasogastric intubation is not an innocuous procedure and is associated mainly with respiratory system complications

- Auxiliary techniques should be used in order to prevent these kinds of complications

Contributors $\mathrm{HJC}$ was responsible for the data collection and analysis, drafting the article and final approval of the version to be published. JC was responsible for the data collection and analysis, and final approval of the version to be published. BN and MP were responsible for the critical revision and final approval of the version to be published. All authors read and approved the final manuscript.

Competing interests None declared.

Patient consent Obtained.

Provenance and peer review Not commissioned; externally peer reviewed.

(c) BMJ Publishing Group Ltd (unless otherwise stated in the text of the article) 2017. All rights reserved. No commercial use is permitted unless otherwise expressly granted.

\section{REFERENCES}

1 Isik A, Firat D, Peker K, et al. A case report of esophageal perforation: complication of nasogastric tube placement. Am J Case Rep 2014;15:168-71.

2 Pillai JB, Vegas A, Brister S. Thoracic complications of nasogastric tube: review of safe practice. Interact Cardiovasc Thorac Surg 2005;4:429-33.

3 Godoy MC, Leitman BS, de Groot PM, et al. Chest radiography in the ICU: part 1, evaluation of airway, enteric, and pleural tubes. AJR Am J Roentgenol 2012;198:563-71. 
Copyright 2017 BMJ Publishing Group. All rights reserved. For permission to reuse any of this content visit http://group.bmj.com/group/rights-licensing/permissions.

BMJ Case Report Fellows may re-use this article for personal use and teaching without any further permission.

Become a Fellow of BMJ Case Reports today and you can:

- Submit as many cases as you like

- Enjoy fast sympathetic peer review and rapid publication of accepted articles

Access all the published articles

- Re-use any of the published material for personal use and teaching without further permission

For information on Institutional Fellowships contact consortiasales@bmjgroup.com

Visit casereports.bmj.com for more articles like this and to become a Fellow 